\title{
PENGARUH PAD, DAU, DAK TERHADAP IPM DENGAN BELANJA MODAL SEBAGAI VARIABEL INTERVENING (Studi Pada Kabupaten/Kota Di Provinsi Papua Tahun 2009 -2013)
}

\author{
Ayu Aldi Raviyanti, Sri Rahayu dan Dewa Putra Krishna Mahardika \\ Fakultas Ekonomi dan Bisnis Universitas Telkom \\ Email: ayu.aldi77@gmail.com
}

\begin{abstract}
One way to measure the success or performance of a country or region in the field of human development used the Human Development Index (HDI). Human Development Index (HDI) is a composite index to measure the achievement of human development based on a number of basic components of quality of life. The purpose of this study is to determine how much Local Genuine Revenue (PAD), General Allocation Fund (DAU), Special Allocation Fund (DAK), Human Index Development (HDI) and Capital Expenditure in the Regencies/Cities of Papua Provinci for years 2009-2013, as well as determine the influence of PAD, DAU and DAK to HDI with Capital Expenditure as an intervening variable either simultaneously or partially. The method that used in this research is panel data regression using Random Effect Model (REM) with research period of year 2009-2013 using software Eviews 8.0. Total population in this research were 29 regencies/cities. By using purposive sampling, obtained sample of 24 regencies/cities. The results of this study indicate that PAD, DAU, and DAK jointly is influenced on Human Development Index with Capital Expenditure as an intervening variable. Partially, PAD is influenced of positive on HDI through Capital Expenditure, DAU is influenced of positive on HDI through Capital Expenditure, while DAK is not influenced on HDI through Capital Expenditure.
\end{abstract}

Keyword: PAD, DAU, DAK, HDI and Capital Expenditure

\begin{abstract}
Abstrak: Salah satu cara untuk mengukur keberhasilan atau kinerja suatu negara atau wilayah dalam bidang pembangunan manusia digunakan Indeks Pembangunan Manusia (IPM) atau Human Development Index (HDI). Indeks Pembangunan Manusia (IPM) merupakan suatu indeks komposit untuk mengukur capaian pembangunan manusia berbasis sejumlah komponen dasar kualitas hidup. Tujuan penelitian ini adalah untuk mengetahui seberapa besar PAD, DAU, DAK, IPM dan Belanja Modal di Kabupaten/Kota Provinsi Papua selama tahun 2009-2013, serta mengetahui pengaruh PAD, DAU, dan DAK terhadap IPM dengan BM sebagai variabel intervening baik secara simultan maupun parsial. Metode penelitian yang digunakan dalam penelitian ini adalah regresi data panel dengan menggunakan Random Effect Model (REM) dengan waktu penellitian tahun 20092013 dengan mengunakan Aplikasi Eviews 8.0. Jumlah populasi dalam penelitian ini sebanyak 29 kabupaten/kota. Dengan menggunakan purposive sampling diperoleh sampel sebanyak 24 kabupaten/kota. Hasil penelitian ini menunjukkan bahwa PAD, DAU, DAK secara bersama-sama berpengaruh terhadap IPM dengan Belanja Modal sebagai variabel intervening. Secara parsial, PAD berpengaruh positif terhadap IPM melalui Belanja Modal, DAU berpengaruh positif terhadap IPM melalui Belanja Modal, sedangkan DAK tidak berpengaruh terhadap IPM melalui Belanja Modal.
\end{abstract}

Kata Kunci: PAD, DAU, DAK, IPM dan Belanja Modal 


\section{PENDAHULUAN}

Salah satu cara untuk mengukur keberhasilan atau kinerja suatu negara atau wilayah dalam bidang pembangunan manusia digunakan Indeks Pembangunan Manusia (IPM) atau Human Development Index (HDI). Indeks Pembangunan Manusia (IPM) merupakan suatu indeks komposit untuk mengukur capaian pembangunan manusia berbasis sejumlah komponen dasar kualitas hidup. Sebagai ukuran kualitas hidup, IPM dibangun melalui pendekatan tiga dimensi dasar. Dimensi tersebut mencakup umur panjang dan sehat, pengetahuan, dan kehidupan yang layak. Penyediaan data IPM ditujukan sebagai alat perencanaan dan evaluasi kebijakan pemerintah. Salah satu contoh pemanfaatan IPM yang cukup penting adalah sebagai basis dalam alokasi dana untuk daerah, yaitu Dana Alokasi Umum (DAU). (BPS, 2015)

Belanja Modal (BM) merupakan belanja pemerintah daerah yang manfaatnya lebih dari satu tahun anggaran dan akan menambah aset atau kekayaan daerah dan selanjutnya akan menambah belanja yang bersifat rutin seperti biaya pemeliharaan pada kelompok belanja administrasi umum. (Peraturan Pemerintah Nomor 71 Tahun 2010). Dalam penelitian ini, BM digunakan sebagai variabel intervening karena PAD, DAK, dan DAU dapat memberikan pengaruh dalam meningkatkan kesejahteraan masyarakat yang tercermin dengan meningkatnya IPM melalui BM. PAD, DAU, dan DAK tidak dapat berpengaruh secara langsung terhadap IPM. Pengaruhnya terlihat apabila digunakan BM sebagai variabel intervening. Pemerintah daerah menggunakan PAD, DAU, dan DAK untuk membiayai belanja modal seperti membangun sarana dan prasarana publik dengan untuk meningkatkan kesejahteraan masyarakat dan meningkatkan kualitas pembangunan manusia yang pada akhirnya akan meningkatkan IPM suatu daerah.

Pemerintah daerah mengalokasikan dana dalam bentuk belanja modal dalam Anggaran Pendapatan dan Belanja Daerah (APDB). Hal ini bertujuan untuk meningkatkan investasi modal dalam bentuk aset tetap, yakni peralatan, bangunan, infrastruktur, dan harta tetap lainnya. Semakin tinggi tingkat investasi modal diharapkan mampu meningkatkan kualitas layanan publik. Alokasi belanja modal ini didasarkan pada kebutuhan daerah akan sarana dan prasarana, baik untuk kelancaran pelaksanaan tugas pemerintah maupun untuk fasilitas publik. Dalam upaya peningkatan kesejahteraan masyarakat dan kualitas layanan publik, pemerintah daerah hendaknya mampu mengubah proporsi belanja yang dialokasikan untuk tujuan dan hal-hal yang positif, seperti melakukan aktivitas pembangunan yang berkaitan dengan program-program untuk kepentingan publik. (Setyowati dan Suparwati, 2012). Hasil Penelitian yang dilakukan oleh Mirza (2012) menunjukkan bahwa Belanja Modal berpengaruh positif signifikan terhadap IPM.

Pendapatan Asli Daerah, selanjutnya disebut PAD adalah pendapatan yang diperoleh daerah yang dipungut berdasarkan peraturan daerah sesuai dengan peraturan perundangundangan. PAD merupakan pendapatan daerah yang bersumber dari hasil pajak daerah, hasil retribusi daerah, hasil pengelolaan kekayaan daerah yang dipisahkan, dan Lain lain yang sah. (Undang-undang Nomor 33 Tahun 2004). PAD bertujuan memberikan kewenangan kepada pemerintah daerah untuk mendanai pelaksanaan otonomi daerah sesuai dengan potensi daerah sebagai perwujudan desentralisasi. Realisasi dari PAD dialokasikan terhadap kebutuhan pembangunan daerah seperti sarana dan prasarana transportasi, tempat ibadah, sarana pendidikan dan pembangunan lainnya yang bertujuan untuk meningkatkan kesejahteraan masyarakat. (Setyowati dan Suparwati, 2012). Dengan meningkatnya PAD, maka dapat meningkatkan BM dalam hal pengadaan sarana dan 
prasarana serta pembangunan lainnya sebagai upaya untuk meningkatkan kesejahteraan masyarakat dan pembangunan manusia yang pada akhirnya akan meningkatkan IPM. Amalia dan Purbadharmaja (2014) melakukan penelitian mengenai kemandirian keuangan daerah (PAD) terhadap IPM. Hasilnya menunjukkan bahwa kemandirian keuangan daerah berpengaruh positif dan signifikan terhadap IPM. Hasil penelitian Setyowati dan Suparwati (2012) menunjukkan bahwa PAD berpengaruh positif terhadap IPM melalui BM. Berbeda dengan hasil penelitian yang dilakukan oleh Wandira (2013) yang menunjukkan bahwa PAD tidak berpengaruh pada BM.

Dana Alokasi Umum, selanjutnya disebut DAU adalah dana yang bersumber dari pendapatan Anggaran Pendapatan dan Belanja Negara (APBN) yang dialokasikan dengan tujuan pemerataan kemampuan keuangan antar-daerah untuk mendanai kebutuhan daerah dalam rangka pelaksanaan desentralisasi. (Undang-undang Nomor 33 Tahun 2004). Christy dan Adi telah melakukan penelitian mengenai "Hubungan antara Dana Alokasi Umum, Belanja Modal dan Kualitas Pembangunan Manusia" pada tahun 2009. Variabel Kualitas Pembangunan Manusia diproksikan oleh Indeks Pembangunan Manusia. Hasilnya menunjukkan bahwa DAU berpengaruh terhadap BM, dan BM berpengaruh terhadap IPM. Hal ini menunjukkan bahwa kebijakan DAU untuk meningkatkan BM merupakan langkah yang efektif untuk meningkatkan IPM. Setyowati dan Suparwati (2012) menunjukkan bahwa DAU berpengaruh positif terhadap IPM dengan Belanja Modal sebagai variabel intervening. Di beberapa daerah, peran DAU sangat signifikan karena kebijakan BM lebih didominasi oleh jumlah DAU daripada PAD. Hal ini memberikan indikasi kuat bahwa perilaku BM akan sangat dipengaruhi oleh sumber penerimaan ini. Hasil penelitian Aprizay et al (2014) juga menunjukkan bahwa DAU berpengaruh terhadap Belanja Modal. Berbeda dengan hasil penelitian yang dilakukan oleh Machmud (2013), yang menunjukkan bahwa DAU tidak berpengaruh terhadap Belanja Modal.

Dana Alokasi Khusus, selanjutnya disebut DAK, adalah dana yang bersumber dari pendapatan Anggaran Pendapatan dan Belanja Daerah (APBN) yang dialokasikan kepada daerah tertentu dengan tujuan untuk membantu mendanai kegiatan khusus yang merupakan urusan daerah dan sesuai dengan prioritas nasional. DAK dialokasikan kepada daerah tertentu untuk mendanai kegiatan khusus yang merupakan urusan daerah. (Undangundang Nomor 33 Tahun 2004). Keberadaan DAK penting bagi pembangunan daerah. Hal ini disebabkan oleh komponen utama dana perimbangan yang berbentuk DAU pada umumnya hanya mencukupi untuk memenuhi kebutuhan belanja birokrasi. Oleh karena itu, penggunaan dan pemanfaatan DAK di daerah menjadi faktor penting dalam keseluruhan program pembangunan daerah pada khususnya dan pembangunan nasional pada umumnya. (Setyowati dan Suparwati, 2012). Penelitian mengenai hubungan. Penelitian mengenai DAK telah dilakukan oleh Nuarisa dan Pelealu pada tahun 2013. Namun variabel dependennya menggunakan BM. Hasilnya sama-sama menunjukkan bahwa DAK berpengaruh positif signifikan terhadap BM. Berbeda dengan penelitian yang dilakukan oleh Ardiansyah dan Widyaningsih (2014) yang menunjukkan bahwa DAK tidak mampu meningkatkan IPM.

Gambar di bawah ini menunjukkan adanya perubahan Indeks Pembangunan Manusia (IPM), Pendapatan Asli Daerah (PAD), Dana Alokasi Umum (DAU), Dana Alokasi Khusus (DAK), dan Belanja Modal (BM) di Provinsi Papua selama lima tahun, yaitu mulai tahun 2009 hingga tahun 2013. Variabel IPM dapat dilihat dari sumbu vertikal 
kanan. Sedangkan variabel PAD, DAU, DAK, dan BM dapat dilihat dari sumbu vertikal kiri.

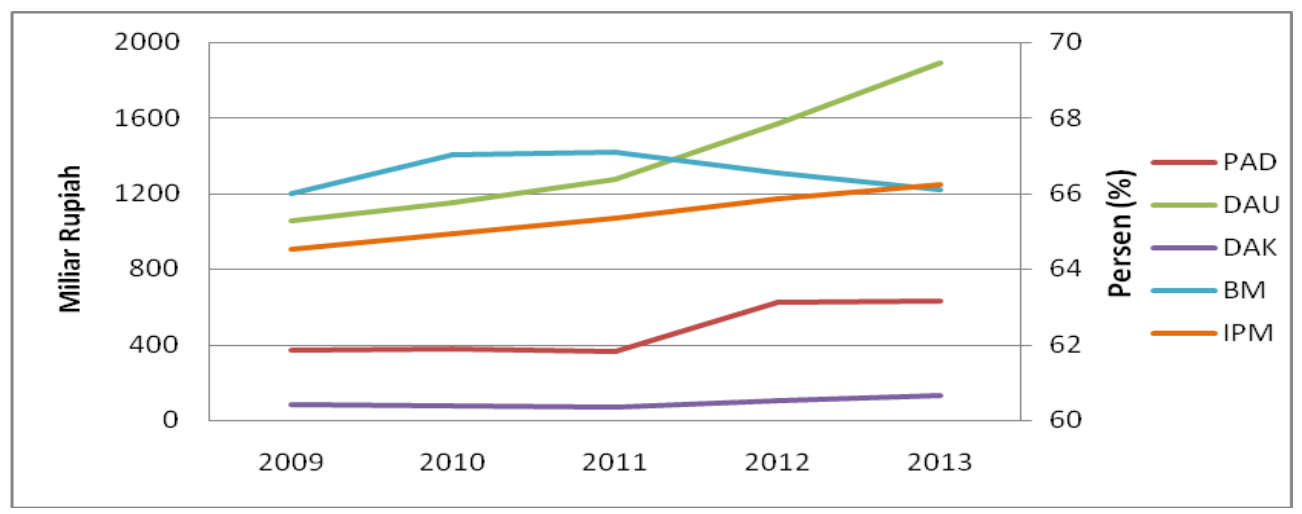

Gambar 1. PAD, DAU, DAK, BM dan IPM Provinsi Papua Tahun 2009 - 2013

Gambar 1 menunjukkan bahwa variabel IPM mengalami kenaikan setiap tahun, namun kenaikannya relatif rendah. Sedangkan variabel independen mengalami peningkatan yang tinggi. Berdasarkan grafik tersebut dapat kita lihat bahwa terdapat ketidaksesuaian antara teori yang ada dengan fakta yang terjadi pada Provinsi Papua, dimana variabel dependen (IPM) mengalami peningkatan yang rendah, tetapi variabel independen (PAD, DAU, dan DAK) mengalami peningkatan yang tinggi. Terjadi ketidakseimbangan antara IPM dengan PAD, DAU, DAK dan BM. Dengan kenaikan PAD, DAU, dan DAK yang tinggi, seharusnya IPM juga mengalami kenaikan yang tinggi.Hal tersebut terlihat pada grafik DAU yang mengalami peningkatan yang tinggi pada tahun 2012 dan tahun 2013, tetapi tidak mempengaruhi peningkatan IPM yang tinggi pula. Peningkatan IPM relatif rendah. Begitu pula dengan BM yang mengalami penurunan pada tahun 2012 dan tahun 2013. Sedangkan PAD, DAU dan DAK mengalami peningkatan yang tinggi pada tahun tersebut. Dengan meningkatnya PAD, DAU, dan DAK, seharusnya BM juga mengalami peningkatan, sehingga dapat meningkatkan IPM.

Tabel di bawah ini menunjukkan persentase kenaikan masing-masing variabel yang terjadi pada Provinsi Papua setiap tahunnya mulai dari tahun 2010 hingga tahun 2013.

Tabel 1. Persentase Kenaikan IPM, PAD, DAU, DAK dan BM Provinsi Papua Tahun

\begin{tabular}{ccccc}
\hline \multicolumn{5}{c}{$2010-2013$} \\
\hline Variabel & 2010 & 2011 & 2012 & 2013 \\
\hline IPM & $0,63 \%$ & $0,64 \%$ & $0,74 \%$ & $0,60 \%$ \\
PAD & $2,71 \%$ & $-4,66 \%$ & $41,73 \%$ & $1,67 \%$ \\
DAU & $7,86 \%$ & $10,01 \%$ & $18,70 \%$ & $16,91 \%$ \\
DAK & $-8,28 \%$ & $-4,08 \%$ & $32,09 \%$ & $20,69 \%$ \\
BM & $14,60 \%$ & $1,20 \%$ & $-8,59 \%$ & $-7,24 \%$
\end{tabular}

Sumber : Dirjen Perimbangan Keuangan dan Badan Pusat Statistik, 2015 (data diolah) 
Dapat dilihat pada Tabel 1 bahwa IPM Papua mengalami kenaikan selama lima tahun berturut-turut, yaitu tahun 2009 hingga tahun 2013. Namun, kenaikan indeksnya rendah. Rata-rata kenaikan IPM di Provinsi Papua hanya sebesar 0,6\%. Pada tahun 2010, PAD meningkat sebesar $2,71 \%$. Tetapi IPM hanya meningkat sebesar $0,63 \%$. Persentase peningkatan IPM tidak seimbang dengan persentse peningkatan PAD. Begitu juga dengan DAU, DAK dan BM. Persentase peningkatan IPM tidak seimbang dengan persentase peningkatan DAU, DAK, dan BM. Ketidakseimbangan peningkatan ini terlihat jelas pada tahun 2012, dimana PAD meningkat sebesar 41,73\%, DAU meningkat sebesar $18,70 \%$ dan DAK meningkat sebesar 32,09\%. Tetapi BM malah mengalami penurunan sebesar $8,59 \%$ dan IPM hanya meningkat sebesar $0,74 \%$. Seharusnya pada tahun 2012 , BM dan IPM meningkat lebih tinggi karena dana yang diperoleh Pemerintah Provinsi Papua dalam bentuk PAD, DAU dan DAK jauh lebih besar dari tahun-tahun sebelumnya. Pemerintah seharusnya bisa meningkatkan IPM yang jauh lebih tinggi dengan memanfaatkan sumber penerimaan tersebut agar pembangunan di Papua bisa menunjukkan adanya keberhasilan.

\section{KAJIAN TEORI}

Indeks Pembangunan Manusia (IPM). Indeks Pembangunan Manusia (IPM) mengukur capaian pembangunan manusia berbasis sejumlah komponen dasar kualitas hidup. Sebagai ukuran kualitas hidup, IPM dibangun melalui pendekatan tiga dimensi dasar. Dimensi tersebut mencakup umur panjang dan sehat, pengetahuan, dan kehidupan yang layak. Untuk mengukur dimensi kesehatan, digunakan angka harapan hidup waktu lahir. Selanjutnya untuk mengukur dimensi pengetahuan digunakan gabungan indikator angka melek huruf dan rata-rata lama sekolah. Adapun untuk mengukur dimensi hidup layak digunakan indikator kemampuan daya beli masyarakat terhadap sejumlah kebutuhan pokok yang dilihat dari rata-rata besarnya pengeluaran per kapita sebagai pendekatan pendapatan yang mewakili capaian pembangunan untuk hidup layak. (BPS, 2015)

Berdasarkan kajian aspek status pembangunan manusia, tinggi rendahnya status pembangunan manusia (IPM) dibedakan menjadi empat golongan, yaitu: (1) Tingkatan rendah, jika IPM < 50; (2) Tingkatan menengah-bawah, jika $50<$ IPM < 66; (3) Tingkatan menengah-atas, jika $66<$ IPM < 80; (4) Tingkatan atas, jika IPM > 80

Pendapatan Asli Daerah (PAD). Pendapatan Asli Daerah yang selanjutnya disingkat PAD adalah pendapatan yang diperoleh daerah yang dipungut berdasarkan peraturan daerah sesuai dengan peraturan perundang-undangan. Besarnya nilai PAD diperoleh dari jumlah seluruh PAD yang tertera dalam Laporan Keuangan Pemerintah Daerah. Pendapatan Asli Daerah (PAD) digunakan untuk belanja pembangunan/belanja modal daerah. (Undang-Undang Nomor 33 Tahun 2004)

Dana Alokasi Umum (DAU). Dana Alokasi Umum, selanjutnya disebut DAU adalah dana yang bersumber dari pendapatan Anggaran Pendapatan dan Belanja Negara (APBN) yang dialokasikan untuk provinsi dan kabupaten/kota dengan tujuan pemerataan kemampuan keuangan antardaerah untuk mendanai kebutuhan daerah dalam rangka pelaksanaan desentralisasi. DAU dialokasikan untuk provinsi dan kabupaten/kota. Besarnya nilai DAU diperoleh dari jumlah seluruh DAU yang tertera dalam Laporan Keuangan Pemerintah Daerah. (Undang-Undang Nomor 33 Tahun 2004) 
Dana Alokasi Khusus (DAK). Dana Alokasi Khusus, selanjutnya disebut DAK adalah dana yang bersumber dari pendapatan APBN yang dialokasikan kepada daerah tertentu dengan tujuan untuk membantu mendanai kegiatan khusus yang merupakan urusan daerah dan sesuai dengan prioritas nasional sesuai dengan fungsi yang telah ditetapkan dalam APBN. Besarnya nilai DAK diperoleh dari jumlah seluruh DAK yang tertera dalam Laporan Keuangan Pemerintah Daerah. Dana Alokasi Khusus (DAK) digunakan untuk mendanai kegiatan khusus yang berhubungan dengan pemerintahan. Salah satunya adalah untuk pengadaan fasilitas kesehatan. (Undang-Undang Nomor 33 Tahun 2004)

Belanja Modal (BM). Belanja Modal (BM) merupakan belanja pemerintah yang manfaatnya lebih dari satu tahun anggaran dan akan menambah aset atau kekayaan daerah dan selanjutnya akan menambah belanja yang bersifat rutin lebih dari satu tahun seperti biaya pemeliharaan pada kelompok belanja administrasi dan umum. Besarnya nilai Belanja Modal dapat dilihat dari Laporan Keuangan Pemerintah Daerah. (Peraturan Pemerintah Nomor 71 Tahun 2010)

Pengaruh Pendapatan Asli Daerah terhadap Indeks Pembangunan Manusia dengan Belanja Modal sebagai Variabel Intervening. Pendapatan Asli Daerah (PAD) digunakan untuk belanja pembangunan/belanja modal daerah. Apabila PAD di suatu daerah tinggi, maka akan mampu membiayai belanja modal yang besar. Salah satunya adalah untuk membangun sarana dan prasarana sekolah untuk meningkatkan mutu pendidikan serta membangun infrastruktur khususnya di bidang kesehatan untuk meningkatkan kesejahteraan masyarakat di daerah tersebut. Dengan demikian, kualitas pembangunan manusia akan meningkat pula, sehingga pada akhirnya dapat meningkatkan Indeks Pembangunan Manusia. Maka, dapat disimpulkan bahwa semakin besar kemampuan Pendapatan Asli Daerah dalam membiayai belanja modal maka akan dapat meningkatkan Indeks Pembangunan Manusia.

Pernyataan di atas didukung oleh penelitian Setyowati dan Suparwati pada tahun 2012. Menurut Setyowati dan Suparwati (2012), PAD dapat digunakan untuk pembangunan jalan raya yang bersumber dari pajak kendaraan bermotor dan pajak bahan bakar. Di samping itu, pembangunan fasilitas kesehatan dapat bersumber dari retribusi pelayanan kesehatan yanng diberikan oleh pemerintah daerah. Dalam hal ini, dimensi umur panjang dan sehat dalam IPM dapat tercapai dengan pembangunan fasilitas kesehatan.

\footnotetext{
Pengaruh Dana Alokasi Umum terhadap Indeks Pembangunan Manusia dengan Belanja Modal sebagai Variabel Intervening. Dana Alokasi Umum (DAU) dialokasikan untuk membiayai belanja modal salah satunya. Belanja modal dialokasikan untuk membangun sarana dan prasarana yang bertujuan untuk memajukan daerah serta meningkatkan kesejahteraan masyarakat. Hal tersebut dapat meningkatkan Indeks Pembangunan Manusia. Maka dapat disimpulkan bahwa semakin besar kemampuan Dana Alokasi Umum dalam membiayai belanja modal, maka akan meningkatkan Indeks Pembangunan Manusia.

Pernyataan di atas didukung oleh penelitian Setyowati dan Suparwati pada tahun 2012. Menurut Setyowati dan Suparwati (2012), DAU adalah dana yang berasal dari APBN yang dialokasikan dengan tujuan pemerataan keuangan antardaerah untuk membiayai kebutuhan pengeluarannya dalam rangka pelaksanaan desentralisasi.
} 
Penggunaan dana ini diharapkan untuk keperluan yang berorientasi pada kesejahteraan masyarakat yang merupakan tuntutan dari otonomi daerah.

Pengaruh Dana Alokasi Khusus terhadap Indeks Pembangunan Manusia dengan Belanja Modal sebagai Variabel Intervening. Dana Alokasi Khusus (DAK) digunakan untuk mendanai kegiatan khusus yang berhubungan dengan pemerintahan. Salah satunya adalah untuk pengadaan fasilitas kesehatan. Dalam hal ini DAK digunakan untuk membiayai belanja modal. Apabila DAK yang alokasikan dari pemerintah pusat ke pemerintah daerah tinggi, maka belanja modal tinggi karen DAK digunakan untuk membiayai belanja modal. Dengan Belanja Modal yang tinggi, diharapkan akan meningkatkan pembangunan manusia. Dalam hal ini akan meningkatkan IPM di daerah tersebut. Semakin besar kemampuan Dana Alokasi Khusus dalam membiayai belanja modal, maka akan meningkatkan Indeks Pembangunan Manusia.

Pernyataan ini didukung oleh penelitian yang dilakukan oleh Setyowati dan Suparwati pada tahun 2012. Menurut Setyowati dan Suparwati (2012), DAK dialokasikan dalam APBN untuk daerah-daerah tertentu dalam rangka mendanai kegiatan khusus yang merupakan urusan daerah dan termasuk dalam program prioritas nasional. Penggunaan dan pemanfaatan DAK di daerah menjadi faktor penting dalam keseluruhan program pembangunan daerah pada khususnya dan pembangunan nasional pada umumnya. APBN mengalokasikan DAK untuk membiayai pelayanan publik tertentu yang disediakan oleh pemerintah kabupaten/kota. Tujuannya untuk mengurangi kesenjangan pelayanan publik antardaerah. DAK juga berperan cukup penting dalam meningkatkan kapasitas belanja modal pemerintah daerah yang terus mengalami peningkatan setiap tahunnya. Hal ini dapat mendorong pemerintah daerah untuk meningkatkan mutu kualitas pembangunan manusia melalui pengalokasian anggaran belanja modal yang secara otomatis beriorientasi pada kesejahteraan publik. Apabila DAK dikelola dengan baik, maka dapat memperbaiki mutu pendidikan dan meningkatkan pelayanan kesehatan serta mengurangi kerusakan infrastruktur.

Berdasarkan teori dan penjelasan diatas, dapat diidentifikasi tiga variabel independen yaitu Pendapatan Asli Daerah $\left(\mathrm{X}_{1}\right)$ dan Dana Alokasi Umum $\left(\mathrm{X}_{2}\right)$ dan Dana Alokasi Khusus $\left(\mathrm{X}_{3}\right)$ yang diperkirakan akan mempengaruhi Indeks Pembangunan Manusia (Y) melalui Belanja Modal (Z) baik secara simultan maupun parsial. Secara ringkas model kerangka pemikiran dapat dilihat pada Gambar di bawah ini.

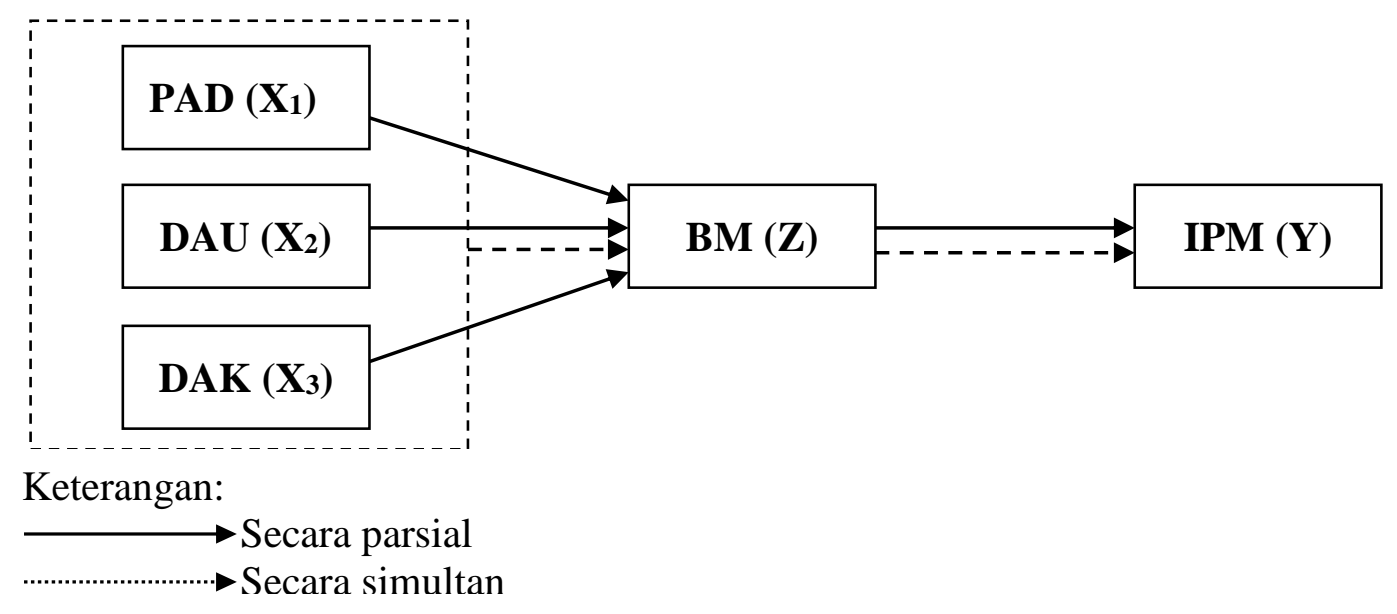

Gambar 2. Kerangka Pemikiran 
Hipotesis. Berdasarkan teori dan kerangka pemikiran di atas, maka penelitian ini memiliki hipotesis sebagai berikut.

$\mathrm{H}_{1}$ : Pendapatan Asli Daerah, Dana Alokasi Umum, dan Dana Alokasi Khusus secara bersama-sama berpengaruh terhadap Indeks Pembangunan Manusia dengan Belanja Modal sebagai variabel intervening.

$\mathrm{H}_{2}$ : Pendapatan Asli Daerah berpengaruh positif terhadap Indeks Pembangunan Manusia dengan Belanja Modal sebagai variabel intervening

$\mathrm{H}_{3}$ : Dana Alokasi Umum berpengaruh positif terhadap Indeks Pembangunan Manusia dengan Belanja Modal sebagai variabel intervening

$\mathrm{H}_{4}$ : Dana Alokasi Khusus berpengaruh positif terhadap Indeks Pembangunan Manusia dengan Belanja Modal sebagai variabel intervening

\section{METODE}

Populasi dan Sampel. Populasi dalam penelitian ini adalah Laporan Keuangan Pemerintah Daerah Kabupaten/Kota di Provinsi Papua tahun 2009-2013. Teknik sampel yang digunakan dalam penelitian ini adalah purposive sampling dengan kriteria diantaranya: (a) Kabupaten/Kota yang ada di Provinsi Papua, (b) Tidak menerbitkan Laporan Keuangan selama lima tahun berturut dari tahun 2009

Berdasarkan kriteria di atas maka diperoleh 120 data observasi yang terdiri dari 24 kabupaten/kota dengan periode penelitian selama lima tahun.

Teknik Analisis Data. Teknik analisis yang digunakan dalam penelitian ini menggunakan analisis statistik deskriptif dan regresi data panel dengan random effect model. Pengujian menggunakan Random Effect Model terdiri dari dua tahap. Tahap pertama menguji variabel independen dan variabel intervening. Tahap kedua menguji variabel independen dan variabel dependen melalui variabel intervening atau menguji variabel intervening terhadap variabel dependen. Sehingga, persamaan regresi dalam penelitian ada dua persamaan.

Tahap 1:

$$
B M=\propto+\beta_{1} P A D+\beta_{2} D A U+\beta_{3} D A K+\varepsilon_{1}
$$

Keterangan: $\mathrm{BM}=$ Belanja Modal PAD = Pendapatan Asli Daerah DAU = Dana Alokasi Umum; DAK = Dana Alokasi Khusus; $\propto$ Konstanta; $\boldsymbol{\varepsilon}_{\mathbf{1}}=$ Error term; $\beta_{1}, \quad \beta_{2}, \beta_{3}=$ Varians BM yang tidak dijelakan oleh PAD, DAU, dan DAK

Tahap 2:

$$
I P M=\propto+\beta_{\mathbf{4}} B M+\varepsilon_{\mathbf{2}}
$$

Keterangan: $\mathrm{IPM}=$ Indeks Pembangunan Manusia; $\mathrm{BM}=$ Belanja Modal; $\propto \boldsymbol{\alpha}=$ Konstanta; $\quad \boldsymbol{\varepsilon}_{\mathbf{2}}=$ Error term; $\beta_{4}=$ Varians Variabel IPM yang tidak dijelaskan oleh $\mathrm{BM}$

\section{HASIL DAN PEMBAHASAN}

Statistik Deskriptif. Hasil statistik deskriptif setiap variabel operasional disajikan pada tabel berikut ini. Dari data tersebut dapat dilihat bahwa data variabel IPM, DAU, DAK dan BM Kabupaten/Kota di Provinsi Papua selama tahun 2009-2013 berkelompok atau 
tidak bervariasi. Sedangkan variabel PAD memiliki nilai mean yang lebih kecil dari nilai standar deviasinya. Artinya bahwa data variabel PAD Kabupaten/Kota di Provinsi Papua selama tahun 2009-2013 bervariasi.

Tabel 2. Hasil Statistik Deskriptif

\begin{tabular}{cccccc}
\hline & PAD & DAU & DAK & BM & IPM \\
\hline Mean & 2.38 & 41.39 & 6.95 & 20.09 & 60.07 \\
Std. Dev. & 4.09 & 15.26 & 2.85 & 9.09 & 9.33 \\
Maximum & 34.46 & 103.95 & 18.15 & 51.04 & 77.12 \\
Minimum & 0.07 & 7.46 & 1.87 & 0.00 & 47.74 \\
Observations & 120 & 120 & 120 & 120 & 120 \\
\hline
\end{tabular}

Sumber: Output Eviews 8.0 (data yang telah diolah)

Selama tahun 2009-2013, masih banyak kabupaten/kota yang memiliki PAD di bawah rata-rata. Hal ini disebabkan karena ada kabupaten/kota yang memiliki PAD jauh lebih tinggi dari nilai rata-rata PAD jika dibandingkan dengan kabupaten/kota lain. Kabupaten/Kota di Provinsi Papua juga masih tergantung pada dana yang diberikan oleh pemerintah pusat sehingga kemandirian kabupaten/kota untuk menghasilkan penerimaan sendiri berupa PAD masih sangat kurang.

Rata-rata DAU Kabupaten/Kota di Provinsi Papua lebih besar dari rata-rata PAD, menunjukkan bahwa pemerintah daerah masih sangat bergantung pada dana dari pemerintah pusat dalam menjalankan kegiatan pemerintahan dan masih belum optimalnya pemerintah daerah dalam mengembangkan potensi yang ada pada daerah sehingga pendapatan yang dihasilkan masih minim. Belanja modal yang dilakukan oleh pemerintah Kabupaten/Kota di Provinsi Papua pada tahun 2013 cukup besar, bahkan lebih besar dari tahun-tahun sebelumnya. Belanja modal ini berupa belanja aset daerah. Belanja modal merupakan komponen yang cukup penting karena berkaitan erat dengan pelaksanaan pembangunan di wilayah Kabupaten/Kota di Procvinsi Papua. Nilai Belanja Modal tertinggi dimiliki oleh Kabupaten Merauke. Hal ini menunjukkan bahwa pembangunan dan perbaikan infrastruktur di Kabupaten Merauke besar. Tujuannya adalah meningkatkan kesejahteraan masyarakat.

Rata-rata variabel IPM sebesar 60,07\%. Hal ini menunjukkan bahwa IPM Kabupaten/Kota di Provinsi Papua termasuk ke dalam tingkatan menengah ke bawah dimana syarat IPM untuk tingkatan menengah ke bawah adalah $50<$ IPM $<66$. Kabupaten Nduga selalu memperoleh IPM terendah setiap tahunnya. IPM yang dimiliki oleh Kabupaten Nduga jauh dari nilai rata-rata. Hal ini menyebabkan IPM Provinsi Papua selalu berada di urutan terendah setiap tahunnya. Dalam upaya mempercepat pembangunan menuju Papua bangkit, mandiri dan sejahtera, pemerintah Provinsi Papua meluncurkan program "Gerakan Membangun Masyarakat Harapan Seluruh Rakyat Papua" atau Gerbang Mas Papua dengan beberapa agenda prioritas pada beberapa aspek seperti pendidikan, kesehatan, ekonomi, dan pembangunan infrastruktur daerah sebagai akses untuk meningkatkan perekonomian masyarakat. Hasil akhir dari seluruh proses pembangunan tersebut adalah untuk kesejahteraan penduduk.

Uji Chow. Berdasarkan hasil Uji Chow, diperoleh nilai probabilitas cross section $F$ sebesar 0,00000 lebih kecil dari taraf signifikansi $(0,00000<0,05)$, maka penelitian ini menggunakan metode fixed effect. 
Tabel 3. Hasil Uji Chow

Redundant Fixed Effects Tests

Pool: Uji Chow

Test cross-section fixed effects

Cross-section F

Effects Test

Statistic

d.f.

Prob.

Cross-section Chi-square

4.224258

$(23,93)$

0.0000

Sumber : Eviews 8.0 (data diolah)

85.830649

23

0.0000

Uji Hausman. Selanjutnya dilakukan uji Hausman, dan diperoleh nilai probabilitas cross section random ( $p$-value) sebesar 0.1669>0.05, maka sesuai dengan ketentuan pengambilan keputusan bahwa regresi data panel menggunakan metode random effect. Berdasarkan uji model data panel, maka hasil yang digunakan pada penelitian ini adalah random effect model.

Tabel 4. Hasil Uji Hausman

Correlated Random Effects - Hausman Test

Pool: Uji Hausman

Test cross-section random effects

\begin{tabular}{cccc}
\hline Test Summary & Chi-Sq. Statistic & Chi-Sq. d.f. & Prob. \\
\hline Cross-section random & 5.068399 & 3 & $\mathbf{0 . 1 6 6 9}$ \\
\hline Sumber : Eviews 8.0 (data diolah) & & &
\end{tabular}

Hasil Estimasi Regresi Data Panel. Hasil estimasi uji random effect model dalam penelitian ini disajikan pada tabel di bawah ini.

Tabel 5. Random Effect Model Tahap 1

\begin{tabular}{lcllc}
\hline \multicolumn{1}{c}{ Variable } & Coefficient & Std. Error & t-Statistic & Prob. \\
\hline C & 6.585112 & 2.142173 & 3.074034 & 0.0026 \\
PAD? & 0.439444 & 0.196634 & 2.234832 & 0.0273 \\
DAU? & 0.219442 & 0.060612 & 3.620452 & 0.0004 \\
DAK? & 0.485768 & 0.281693 & 1.724456 & 0.0873 \\
\hline \multicolumn{5}{c}{ Weighted Statistics } \\
\hline R-squared & 0.318930 & Mean dependent var & 9.619723 \\
Adjusted R-squared & 0.301316 & S.D. dependent var & 6.534394 \\
S.E. of regression & 5.461924 & Sum squared resid & 3460.583 \\
F-statistic & 18.10677 & Durbin-Watson stat & 1.405066 \\
Prob(F-statistic) & 0.000000 & & \\
\hline Sumber. Output Evin
\end{tabular}

Sumber: Output Eviews 8.0 (data yang telah diolah) 
Raviyanti, Rahayu dan Mahardika: Pemgaruh PAD, DAU, DAK Terhadap IPM...

Tabel 6. Random Effect Model Tahap 2

\begin{tabular}{lcllc}
\hline \multicolumn{1}{c}{ Variable } & Coefficient & Std. Error & t-Statistic & Prob. \\
\hline C & 0.593826 & 0.019703 & 30.13861 & 0.0000 \\
BM? & 0.000343 & 0.000117 & 2.921564 & 0.0042 \\
\hline \multicolumn{4}{c}{ Weighted Statistics } \\
\hline R-squared & 0.067666 & Mean dependent var & 0.019928 \\
Adjusted R-squared & 0.059765 & S.D. dependent var & 0.007319 \\
S.E. of regression & 0.007097 & Sum squared resid & 0.005944 \\
F-statistic & 8.564117 & Durbin-Watson stat & 0.553496 \\
Prob(F-statistic) & 0.004114 & & \\
\hline
\end{tabular}

Sumber: Output Eviews 8.0 (data yang telah diolah)

Berdasarkan tabel di atas dapat diketahui nilai konstanta koefisien sehingga dapat dibentuk persamaan sebagai berikut:

Tahap 1:

$$
\mathrm{BM}=6,585112+0,439444 \mathrm{PAD}+0,219442 \mathrm{DAU}+0,485768 \mathrm{DAK}+\varepsilon_{\mathbf{1}}
$$

Tahap 2:

$\mathrm{IPM}=59,37020+0,003478 \mathrm{BM}+\varepsilon_{\mathbf{2}}$

Koefisien Determinasi $\left(\mathbf{R}^{2}\right)$. Berdasarkan hasil pengujian Random Effect Model pada Tahap 1, diperoleh nilai $\mathrm{R}^{2}$ ((R-Square) sebesar 0,301316 atau 30,13\%. Sedangkan pada pengujian tahap 2, diperoleh nilai $\mathrm{R}^{2}$ sebesar 0,059765 atau 5,98\%. Hal ini mengindikasikan bahwa variabel independen yang terdiri dari PAD, DAU, dan DAK menjelaskan variabel intervening BM sebesar 30,13\% dan variabel BM mampu menjelaskan variabel dependen IPM sebesar 5,98\%. Sedangkan sisanya dijelaskan oleh variabel lain di luar penelitian yang dilakukan oleh peneliti.

Uji Signifikansi Simultan (Uji F). Berdasarkan pengujian tahap 1 secara simultan, diperoleh nilai probabilitas Uji F sebesar 0,00000. Sedangkan pengujian tahap 2, diperoleh nilai probabilitas Uji $\mathrm{F}$ sebesar 0, 004114. Hasil tersebut menunjukkan bahwa nilai probabilitas Uji $F$ lebih kecil dari taraf signifikansi yaitu $0,00000<0,05$, dan $0,004114<0,05$. Hal ini berarti PAD, DAU, dan DAK berpengaruh signifikan terhadap IPM dengan BM sebagai variabel intervening.

Uji Signifikansi Parsial (Uji t). Berdasarkan hasil uji metode random effect model dapat disimpulkan bahwa:

a. Variabel PAD $\left(\mathrm{X}_{1}\right)$ memiliki nilai probabilitas0.0273. Artinya nilai probabilitas lebih kecil dari taraf signifikansi $(0,0273<0.05)$, Dimana BM sebagai variabel intervening (Z) memiliki nilai probabilitas sebesar 0,0042. Sesuai ketentuan pengambilan keputusan maka $\mathrm{Ha}_{2}$ diterima yang berarti PAD memiliki pengaruh signifikan terhadap peningkatan IPM dengan BM sebagai variabel intervening pada 
Kabupaten/Kota di Provinsi Papua secara parsial karena perubahan PAD mengakibatkan perubahan pada IPM melalui BM.

b. Variabel DAU $\left(\mathrm{X}_{2}\right)$ memiliki nilai probabilitas 0.0004 . Artinya nilai probabilitas lebih kecil dari taraf signifikansi $(0,0004<0.05)$ dan BM (Z) memiliki nilai probabilitas sebesar 0,0042. Sesuai ketentuan pengambilan keputusan maka $\mathrm{Ha}_{3}$ diterima yang berarti DAU memiliki pengaruh signifikan terhadap peningkatan IPM dengan BM sebagai variabel intervening pada Kabupaten/Kota di Provinsi Papua secara parsial karena perubahan DAU mengakibatkan perubahan pada IPM melalui BM.

c. Variabel DAK $\left(\mathrm{X}_{3}\right)$ memiliki nilai probabilitas 0.0873 . Artinya nilai probabilitas lebih besar dari taraf signifikansi $(0,0873>0.05)$. Sesuai ketentuan pengambilan keputusan maka $\mathrm{H}_{\mathrm{o} 4}$ diterima yang berarti DAK tidak memiliki pengaruh signifikan terhadap peningkatan IPM dengan BM sebagai variabel intervening pada Kabupaten/Kota di Provinsi Papua secara parsial karena perubahan DAK belum tentu mengakibatkan perubahan pada IPM melalui BM.

Pengaruh Pendapatan Asli Daerah terhadap Indeks Pembangunan Manusia melalui Belanja Modal. Berdasarkan hasil pengujian secara parsial seperti yang ditunjukkan pada Tabel 5 di atas, nilai probabilitas PAD yang diperoleh adalah sebesar 0,0273. Hal ini berarti bahwa PAD berpengaruh terhadap IPM dengan BM sebagai variabel intervening, karena probabilitasnya di bawah 0,05, lebih kecil dari taraf signifikansi. Selain itu, dapat dilihat bahwa koefisien regresi bernilai positif yang menunjukkan bahwa setiap peningkatan satu PAD, maka BM akan mengalami peningkatan sebesar 0,439444 atau 43,9444\% dan IPM meningkat sebesar 0,000343 atau $0,0343 \%$. Hal ini telah sesuai dengan hipotesis yang dirumuskan sebelumnya, yang menyebutkan bahwa PAD berpengaruh positif terhadap IPM dengan BM sebagai variabel intervening. Dapat disimpulkan bahwa apabila PAD meningkat, maka IPM akan meningkat melalui BM sebagai variabel intervening.

Dana Alokasi Umum terhadap Indeks Pembangunan Manusia melalui Belanja Modal. Berdasarkan hasil penelitian, nilai probabilitas yang diperoleh DAU adalah sebesar 0,0004. Artinya DAU berpengaruh signifikan terhadap IPM dengan Belanja Modal sebagai variabel intervening karena nilai probabilitasnya lebih kecil dari taraf signifikansi, yaitu 0,05. Nilai koefisien DAU adalah sebesar 0.219442 yang menunjukkan adanya perubahan ke arah yang positif. Artinya apabila ada kenaikan DAU sebesar satu maka BM akan meningkat sebesar 0,219442 atau 21,9442\%. Dan nilai koefisien BM terhadap IPM juga bernilai positif yang artinya semakin tinggi kemapuan DAU dalam membiayai pengeluaran pemerintah atas belanja modal maka dapat meningkatkan IPM. Hasil penelitian ini telah sesuai dengan hipotesis yang telah dirumuskan sebelumnya. Dimana DAU berpengaruh signifikan terhadap IPM dengan Belanja Modal sebagai variabel intervening. Dapat disimpulkan bahwa apabila DAU di Kabupaten/Kota di Provinsi Papua meningkat, maka IPM akan meningkat pula melalui BM sebagai variabel intervening. 
Dana Alokasi Khusus terhadap Indeks Pembangunan Manusia melalui Belanja Modal. Berdasarkan hasil penelitian yang telah dilakukan DAK memperoleh nilai probabilitas sebesar 0,0837 . Nilai probabilitasnya lebih besar dari taraf signifikansi $(0,0873>0.05)$. Hal ini dapat diartikan bahwa DAK tidak berpengaruh terhadap IPM dengan BM sebagai variabel intervening. Dapat diasumsikan apabila DAK Kabupaten/Kota di Provinsi Papua meningkat, maka belum tentu diikuti dengan IPM yang meningkat melalui BM yang meningkat pula. Sebaliknya, apabila DAK menurun, maka belum tentu diikuti oleh IPM yang menurun melalui BM yang menurun pula. Hasil penelitian ini menunjukkan bahwa terdapat ketidaksesuaian dengan hipotesis yang telah dirumuskan sebelumnya yang menyebutkan bahwa DAK berpengaruh positif terhadap IPM dengan BM sebagai variabel intervening. Hal ini dikarenakan penyaluran DAK di Kabupaten/Kota di Provinsi Papua tidak dialokasikan untuk Belanja Modal yang bertujuan untuk meningkatkan IPM, melainkan dialokasikan untuk belanja lain, seperti belanja operasional atau belanja rutin. Sehingga DAK yang tinggi belum tentu mengakibatkan IPM yang tinggi pula.

\section{PENUTUP}

Simpulan. Hasil penelitian secara simultan menunjukkan bahwa PAD, DAU dan DAK secara bersama-sama berpengaruh positif signifikan terhadap Indeks Pembangunan Manusia dengan Belanja Modal sebagai variabel intervening.

Hasil penelitian secara parsial menunjukkan bahwa: (1) PAD berpengaruh positif signifikan terhadap IPM dengan Belanja Modal sebagai variabel intervening. Hal ini dapat diasumsikan bahwa semakin tinggi kemampuan PAD dalam membiayai Belanja Modal, maka akan meningkatkan IPM; (2) DAU berpengaruh positif signifikan terhadap IPM dengan Belanja Modal sebagai variabel intervening. Hal ini dapat diasumsikan bahwa semakin tinggi kemampuan DAU dalam membiayai Belanja Modal, maka akan meningkatkan IPM; (3) DAK tidak berpengaruh terhadap IPM dengan Belanja Modal sebagai variabel intervening. Hal ini dapat diasumsikan bahwa apabila DAK tinggi maka belum tentu dapat meningkatkan IPM melalui Belanja Modal.

Saran. Saran untuk pengembangan penelitian selanjutnya, disarankan agar peneliti selanjutnya menambah variabel lain seperti Dana Bagi Hasil karena diduga dapat memberikan hasil yang berbeda karena setiap sumber penerimaan daerah memiliki sensitifitas yang berbeda-beda terhadap faktor uji, sehingga bisa mendapatkan hasil yang lebih baik. Hasil penelitian ini diharapkan dapat digunakan sebagai tolak ukur dan tambahan referensi dalam penelitian berikutnya dengan menambah periode penelitian misalnya sepuluh tahun dan menggunakan objek penelitian lain seperti Bengkulu sehingga dapat dilakukan generalisasi atas hasil penelitian tersebut.

Saran bagi Pemerintah Kabupaten/Kota di Provinsi Papua, hasil penelitian ini diharapkan dapat membantu Pemerintah untuk meningkatkan sumber penerimaan daerah dengan tujuan untuk meningkatkan layanan publik berupa kesehatan, pendidikan dan ekonomi sehingga kualitas pembangunan manusianya meningkat. Pemerintah Daerah Kabupaten/Kota di Provinsi Papua lebih giat lagi untuk memperoleh sumber penerimaan daerah ini sehingga dapat digunakan untuk memperbaiki kualitas pelayanan publik dan kualitas pembangunan manusia. Pemerintah juga lebih menekan pengeluaran-pengeluaran pemerintah yang dirasa kurang penting agar sumber penerimaan daerah dapat dialokasikan 
untuk kepentingan publik. Sebaiknya lebih diperhatikan daerah yang memilki IPM yang rendah agar IPM di Provinsi Papua merata.Sebab apabila ada IPM yang rendah di salah satu Kabupaten/Kota di Provinsi Papua akan mempengaruhi besarnya IPM di Provinsi Papua secara keseluruhan.

\section{DAFTAR RUJUKAN}

Amalia, Firda Rizky dan Purbadharmaja, Ida Bagus Putu (2014) Pengaruh Kemandirian Keuangan Daerah dan Keserasian Alokasi Belanja terhadap Indeks Pembangunan Manusia. E-Jurnal Ekonomi Pembangunan Universitas Udayana. ISSN: 2303-0178. 257-264.

Aprizay et al (2014) Pengaruh Pendapatan Asli Daerah, Dana Perimbangan dan Sisa Lebih Pembiayaan Anggaran terhadap Pengalokasian Belanja Modal pada Kabupaten/Kota di Provinsi Aceh. Jurnal Akuntansi, 3(1), 140-149, Februari, ISSN 2302-0164.

Ardiansyah dan Vitalis Ari Widiyaningsih (2014) "Pengaruh Pendapatan Asli Daerah, Dana Alokasi Umum Dan Dana Alokasi Khusus Terhadap Indeks Pembangunan Manusia Kabupaten/Kota Di Propinsi Jawa Tengah". Simposium Nasional Akuntansi XVII Mataram.

Badan Pusat Statistik (2015) www.bps.go.id.

Christy, Fhino Andrea dan Adi, Priyo Hari (2009) Hubungan antara Dana Alokasi Umum, Belanja Modal dan Kualitas Pembangunan Manusia. The $3^{\text {rd }}$ National Conference UKWMS. Surabaya

Machmud, Surya Abdul Amin (2013) "Pengaruh Dana Alokasi Umum (DAU) dan Dana Alokasi Khusus (DAK) terhadap Realisasi Anggaran Belanja Modal Pada Kabupaten/Kota Provinsi Sulawesi Utara”. Jurnal Ilmu Manajemen dan Bisnis. ISSN 2302-6723. 1-10

Mirza, Denni Sulistio (2012) "Pengaruh Kemiskinan, Pertumbuhan Ekonomi dan Belanja Modal terhadap Indeks Pembangunan Manusia di Jawa Tengah Tahun 2006-2009”. Economics Development Analysis Journal. ISSN 2252-6560. 1-15

Nuarisa, Sheila Ardhian (2013) Pengaruh PAD, DAU, dan DAK terhadap Pengalokasian Belanja Modal. Accounting Analysis Journal, ISSN 2252-6765. 89-95.

Pelealu, Andreas (2013) "Pengaruh Dana Alokasi Khusus (DAK), dan Pendapatan Asli Daerah (PAD) terhadap Belanja Modal Pemerintah Kota Manado Tahun 20032012”. Jurnal EMBA, Vol 1, No.1. ISSN 2303-1174. 1189-1197

Peraturan Pemerintah Republik Indonesia Nomor 71 Tahun 2010 tentang Standar Akuntansi Pemerintahan.

Setyowati, Lilis dan Suparwati, Yohana Kus (2012) "Pengaruh Pertumbuhan Ekonomi, DAU, DAK, PAD terhadap Indeks Pembangunan Manusia dengan Pegalokasian Belanja Modal sebagai Variabel Intervening”. Jurnal Prestasi, vol.9, No. 1. ISSN 1411-1497. 113-133.

Undang-Undang Nomor 33 Tahun 2004 tentang Perimbangan Keuangan.

Wandira, Arbie Gugus (2013) "Pengaruh PAD, DAU, DAK, dan DBH terhadap Pengalokasian Belanja Modal”. Accounting Analysis Journal, ISSN 2252-6765. 4451. 